\title{
Performance and economics of production of broiler chickens fed sorghum or millet as replacement for maize in the semi-arid zone of Nigeria
}

\section{${ }^{1}$ Clement ljaduwa Medugu, ${ }^{2}$ Ibrahim Dankasa Kwari, ${ }^{2}$ Joseph Igwebuike, ${ }^{3}$ Iro Nkama, ${ }^{3}$ Ibrahim Dukku Mohammed and ${ }^{4}$ Bruce Hamaker}

\author{
${ }^{1}$ Borno State Agricultural Development Programme (BOSADP) Maiduguri \\ ${ }^{2}$ Department of Animal Science, University of Maiduguri, PMB 1069, Maiduguri - Nigeria \\ ${ }^{3}$ Department of Food Science and Technology, University of Maiduguri, PMB 1069, \\ Maiduguri-Nigeria \\ ${ }^{4}$ Department of Food Science, Purdue University, 1160 Food Science building West \\ Lafayette, IN 47907-1160 \\ ABSTRACT
}

\begin{abstract}
The effects of replacing maize with sorghum or millet on the performance and economics of production of broiler chickens were investigated in a 42 - day feeding trial. One hundred and eighty (180) (Anak-2000) broiler chicks weighing averagely $351.7 \pm 5.7 \mathrm{~g}$ were randomly allotted to four experimental diets in which maize $\left(T_{1}\right)$ control, pearl millet $\left(T_{2}\right)$, low tannin sorghum $\left(T_{3}\right)$ and high tannin sorghum $\left(T_{4}\right)$ served as the energy sources in a randomized block design (RBD). Each treatment consisted of 45 birds and three replicates of fifteen chickens each. There were no significant $(P>0.05)$ differences in productive performance among all the treatment groups. The overall weight gains were 1,788.7, 1,862.0, 1,768.7 and 1,578.3g and feed conversion ratio was 2.45, 2.24, 2.88 and 2.94 respectively for $T_{1}, T_{2}, T_{3}$ and $T_{4}$. The results, however, indicate that the cost per $\mathrm{kg}$ feed and cost of feed per unit weight gain were lowest in millet followed by high-tannin sorghum, low-tannin sorghum and maize-based diets respectively. This suggests that the replacement of maize by these materials would be economical and also cost effective.
\end{abstract}

Keywords: Broiler Chickens, performance, sorghum, millet, maize

\section{INTRODUCTION}

Maize has been the major source of energy in poultry diets. However, inadequate production of this grain and the intense competition for maize between man and livestock especially in the drier areas of the tropics has made poultry rations to be expensive. This high cost and localized scarcity of commercial diets for poultry may, if not addressed, result in lower income to poultry farmers and reduced protein intake among the semi-arid communities.

One important measure that can be taken to alleviate such a threat is the use of alternative energy sources like sorghum and millet. The semi-arid conditions of West Africa having high ambient temperatures of $>$ $38^{\circ} \mathrm{C}$ for most part of the year and low and poorly distributed rainfall make it more conducive for sorghum and millet production.

Some workers (Parthasarathy et al., 2005; Issa et al., 2007) have reported that sorghum grains can play an important role in poultry feed in the Sahelian countries. Other workers (Hancock, 2000, Dowling et al, 2002; Cramer et al, 2003 and Travis et al, 2006) have all shown that sorghum could be a suitable feedstuff in the poultry industry. Cromwell and Coffey (1993) exonerated millet from the anti-nutritional properties (Phytate and tannins) and NRC (1996) has reported that millet has no tannin, contains $5-7 \%$ oil and has higher protein and minerals than maize. The report further revealed that millet can replace maize in the diets of broiler chickens without adverse effects on growth rate or feed conversion ratio. Therefore, the objective of this study was to evaluate the performance and cost effectiveness of feeding maize, millet, high tannin and low tannin sorghum - based diets to broiler chickens.

\section{MATERIALS AND METHODS}

Location of study: This experiment was conducted at the poultry unit of the University of Maiduguri, Teaching and Research Farm. Maiduguri is located at $11.05^{\circ}$ north and $30.05^{\circ}$ east and on an elevation of $364 \mathrm{~m}$ above sea level in the North Eastern part of Nigeria. It is characterized by a semi-arid condition which includes high ambient temperature $\left(>38^{\circ} \mathrm{C}\right)$ during the month of April-May and low relative 
humidity of $30-50 \%$ with minimum of $10 \%$ in February and March and maximum of $90 \%$ in August (Ugherughe and Ekedolum, 1986). The annual rainfall ranges from $500-600 \mathrm{~mm}$ which falls within 3-4 months of the year and dry season is long (8-9 months).

Management of the birds: One hundred and eighty (180) (Anak - 2000) broiler chicks were used for the study which lasted for 42 days. The birds were individually weighed and randomly assigned to four experimental diets at two weeks of age (14 days), the experimental diets contained maize, pearl millet, lowtannin ("chakalere white") and high-tannin ("jigari") sorghum as energy sources in diets I (control), 2, 3 and 4 respectively. Each treatment consisted of 45 birds each and each treatment was replicated three times with 15 birds per replicate. The experimental diets (Table 1) were fed together with clean drinking water ad libitum throughout the experimental period. Standard management practices and routine vaccination were strictly observed.

Sources of grains and feed: The grain samples maize sorghum (chakalere white and jigari) and pearl millet (ex-Borno) were obtained from Maiduguri Monday Market. The commercial feed (broiler starter) was obtained from ECWA Feed, Jos.

Performance Parameters: Body weight, feed consumption and feed conversion ratio were measured as the indices of performance and cost per kilogram of feed and feed cost per kilogram of weight gain were calculated to indicate the economics of production using the different test materials as energy sources.

The test materials and experimental diets were analyzed using AOAC (1990) methods. Data collected were subjected to analyses of variance (Steel and Torrie, 1980) using a randomized block design and where significant differences were observed, means were separated by Duncan's Multiple Range Test (Duncan, 1955).

\section{RESULTS AND DISCUSSION}

The proximate composition of the experimental diets and test ingredients are presented in Tables 1 and 2 respectively. The crude protein levels are higher in millet (14.10\%) and sorghum (11.55 and 12.75\%) compared to maize (10.10\%). The crude protein levels obtained here are slightly higher than the 8.80 ; 12.00 and $9.50 \%$ CP levels reported by Olomu (1995) for maize, millet and sorghum respectively. There is no tannin in maize but tannin levels are
$2.32 \%$ for millet, $1.54 \%$ for low tannin sorghum and $7.44 \%$ for high tannin sorghum. The levels of tannin in the two types of sorghum are comparable to the 2.32 and $5.22 \%$ reported by Pour-Reza and Edriss (1997) for low and high-tannin sorghum varieties.

The crude protein and metabolizable energy levels of the experimental diets were $20.75,21.85,20.95$ and $21.11 \%$, and $3253.38,3395.40,3400.10$ and 3325.16 $\mathrm{Kcal} / \mathrm{kg}$ respectively for the maize, millet, low-tannin sorghum and high-tannin sorghum-based diets. The levels of protein and energy are adequate for finishing broilers. Olomu (1995) recommended 19$21 \% \mathrm{CP}$ and $3000 \mathrm{Kcal} / \mathrm{kg}$ energy for finishing broilers. The protein and energy levels in the diets reflected their levels in the test materials. Final body weight, overall weight gain, daily feed intake, daily weight gain and feed conversion ratio (Table 3 ) showed no significant $(P>0.05)$ differences among all the treatment groups. This result is in conformity with the findings of Pour-Reza and Edriss (1997) who stated that all the dietary maize portion of broiler diets can be replaced with low-tannin sorghum without adverse effects on live weight gain, feed intake and feed conversion ratio. Gualitieni and Rapoccinni (1990) and Jacob et al (1996) have reported that lowtannin sorghum has similar nutritional value with maize. Andrew and Kumar (1992) and NRC (1996) equally observed that millet can fully replace maize in chicken diets without adverse effects on feed efficiency and rate of gain.

Economics of production analysis (Table 3 ) indicated that the highest cost per $\mathrm{kg}$ feed ( $\mathrm{A52.20)}$ was in the maize-based diet compared to $\$ 41.20, \$ 46.80$ and A38.40 respectively for millet, low-tannin sorghum and high-tannin sorghum-based diets. The hightannin sorghum based diet was the cheapest. Feed cost per weight gain was lowest in the millet-based diet followed by the high-tannin sorghum and highest in the maize-based diet.

Considering the weight gain of the birds and the feed cost per weight gain, millet and sorghum can completely replace maize in broiler chicken diets without adverse effects on performance. An added advantage is the reduced cost of feeding the broilers.

\section{ACKNOWLEDGEMENT}

Financial support in part by a grant farm INTSORMIL to University of Maiduguri is gratefully acknowledged. 
Agric. Biol. J. N. Am., 2010, 1(3): 321-325

Table 1: Ingredients and Chemical Composition of the experimental diets \%

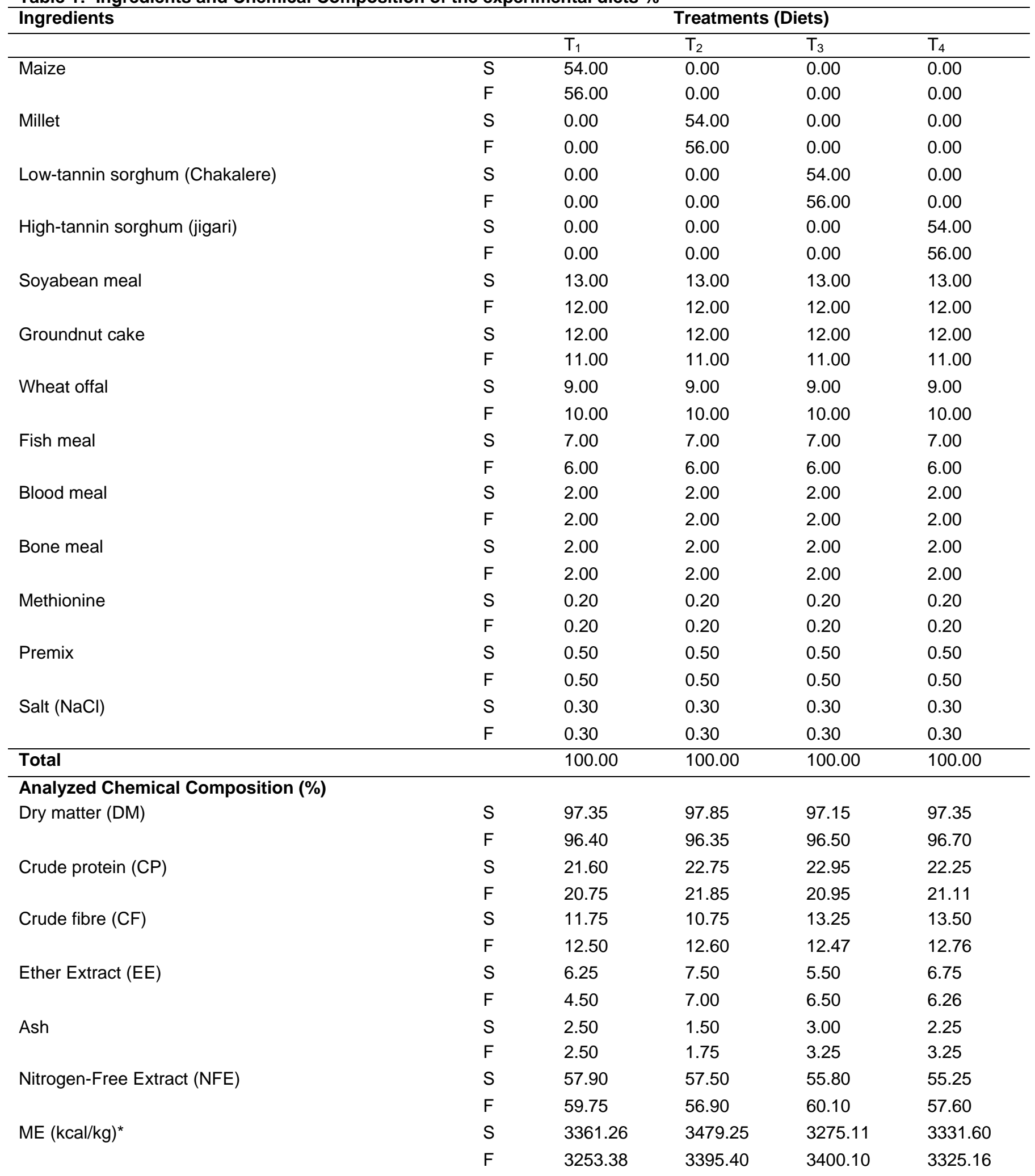

${ }^{*} \mathrm{ME}(\mathrm{Kcal} / \mathrm{kg})=37 \times \% \mathrm{CP}+81 \times \% \mathrm{EE}+35$ x \% NFE (Pauzenga, 1985), S $\quad=$ =Broiler starter diet, $\mathrm{F}=\quad$ Broiler Finisher diet 
Agric. Biol. J. N. Am., 2010, 1(3): 321-325

Table 2: Chemical Composition of Test Ingredients

\begin{tabular}{lllll}
\hline \multirow{2}{*}{ Nutrients (\%) } & \multicolumn{3}{c}{ Test materials } \\
\cline { 2 - 5 } & Maize & Millet & $\begin{array}{l}\text { Low-tannin } \\
\text { (chakalere) }\end{array}$ & $\begin{array}{c}\text { sorghum } \\
\text { High-tannin sorghum } \\
\text { (Jigari) }\end{array}$ \\
\hline Dry matter (DM) & 95.40 & 96.35 & 95.25 & 95.80 \\
Crude protein (CP) & 10.10 & 14.10 & 11.55 & 12.75 \\
Crude fibre (CF) & 5.50 & 6.00 & 5.75 & 7.75 \\
Ether Extract (EE) & 3.25 & 5.50 & 4.25 & 3.50 \\
Ash & 1.00 & 2.25 & 2.25 & 2.00 \\
Nitrogen-Free Extract (NFE) & 75.55 & 68.40 & 71.45 & 69.80 \\
ME (kcal/kg)* & 3318.98 & 3395.40 & 3308.08 & 3233.15 \\
Tannin (\%) & 0.00 & 2.32 & 1.54 & 7.44 \\
\hline
\end{tabular}

The above are means of 3 determinations

${ }^{*} \mathrm{ME}=$ Metabolizable Energy Calculated according to the formula of Pauzenga (1985): ME $=37 \times \% \mathrm{CP}+81 \times \% \mathrm{EE}+35.5 \times \%$ NFE

Table 3: Performance and Economics of production of broiler chickens fed different cereal - based diets

\begin{tabular}{|c|c|c|c|c|c|}
\hline \multirow[b]{2}{*}{ Parameters } & \multicolumn{5}{|c|}{ Treatment (Diets) } \\
\hline & $\mathrm{T}_{1}$ (maize) & $\mathrm{T}_{2}$ (millet) & $\begin{array}{l}\mathrm{T}_{3} \text { (low-tannin } \\
\text { sorghum) }\end{array}$ & $\begin{array}{l}\mathrm{T}_{3} \text { (high-tannin } \\
\text { sorghum) }\end{array}$ & SEM \\
\hline Mean initial live weight (g) & 353.30 & 356.67 & 343.33 & 353.33 & $14.33^{\mathrm{NS}}$ \\
\hline Mean final body weight (g) & 2142.00 & 2218.67 & 2112.00 & 1931.33 & $105.43^{\text {NS }}$ \\
\hline Overall weight gain (g) & 1788.70 & 1862.00 & 1768.67 & 15.78 .33 & $98.11^{\mathrm{NS}}$ \\
\hline Daily feed intake (g) & 97.41 & 94.0 & 98.79 & 100.71 & $3.37^{\mathrm{NS}}$ \\
\hline Daily weight gain (g) & 41.39 & 43.17 & 39.66 & 34.44 & $3.74^{\mathrm{NS}}$ \\
\hline Feed conversion ratio & 2.45 & 2.24 & 2.88 & 2.94 & $0.45^{\mathrm{NS}}$ \\
\hline Total feed intake (g) & 4091.22 & 3949.26 & 4149.18 & 4229.82 & NA \\
\hline Feed cost/kg $(\mathbb{A} / \mathrm{kg})^{\star}$ & 52.20 & 41.20 & 46.80 & 38.40 & NA \\
\hline Total feed cost (A) & 213.56 & 162.73 & 194.18 & 162.43 & NA \\
\hline Feed cost/kg gain $(A / k g)$ & 113.99 & 87.49 & 109.73 & 102.80 & NA \\
\hline
\end{tabular}

$\begin{array}{lll}\text { NS } & = & \text { Not significant }(\mathrm{P}>0.05) \\ \mathrm{SEM} & = & \text { Standard Error of Means } \\ \text { * Feed cost } & \text { was based on the cost of ingredient during the period of study } \\ \text { NSA } & \text { Not statistically analyzed }\end{array}$

\section{REFERENCES}

Andrew, A.J. and Kumar, K.A. (1992). Pearl millet for feed and forage. J Adv Agron. 149:90-139

AOAC (1990). Official Methods of Analysis. $15^{\text {th }}$ ed. Association of Official Analytical Chemists, Washington D.C. USA.

Cramer, K.R., Wilson, K.J., Moritz, J.S. and Beyer, R.S. (2003). Effect of sorghum-based diets subjected to various manufacturing procedures on broiler performance. J Appl. Poult. Res. 12:404-410.

Cromwell, G. L. and Coffey, R. D. (1993). An assessment of the availability of phosphorus in feed ingredients for non- Ruminants. Proceedings of the Maryland Nutrition Conference for Feed Manufacturers. pp.146-158, Maryland USA.

Dowling, L.F., Arndt, C. and Hamaker, B.R. (2002). Economic viability of high digestibility sorghum as feed for market broilers. Agron. J. 94: 1050-1058.

Duncan, D.B. (1955). Multiple Range and F-Test. Biometrics. 11: 1-42.
Gualitieni, M. and Rapaccinni, S. (1990). Sorghum grains in poultry feeding. World's Poultry Sci. J 46: 246 - 254.

Hancock, J.D. (2000). Value of sorghum and sorghum coproducts in diets for livestock. In: Smith W. and R. A. Frederickson (ed.), Sorghum origin, History, Technology and Production. Willey Series Crop. Sci. pp. 731-751

Issa, S., Hancock, J.D., Tuinstra, M.R., Kapran, I. and Kaka, S. (2007). Effects of sorghum variety on growth and carcass characteristics in broiler chicks reared in West Africa. J. Poult. Sci: 86: 69.

Jacob, J.P., Mitaru, N., Mbugu, P.N. and Blair, R. (1996). The effect of substituting Kenyan serena sorghum for maize in broiler chickens starter diets with different dietary protein and methionine levels. Animal Feed Scie Technol. 61:41-56.

NRC (1996). National Research Council, Nutrient requirements of Domestic Animals $9^{\text {th }}$ ed. National Academy Press, Washington, D.C., USA. 
Agric. Biol. J. N. Am., 2010, 1(3): 321-325

Olomu, J.M. (1995). Monogastric Animal Nutrition. Principles and Practices. A. JACHEM Publication, Benin City, Nigeria. pp 320.

Parthasarathy, P.R., Gurava, K.R., Reddy, V.S. and Gowda, C.K. (2005). Linking producers and processors of sorghum for poultry feed. A case study from India. International Crops Research Institute for the Semi Arid Tropics (ICRISAT), New Delhi, India. pp 12

Pauzenga, U. (1985). Feeding Parent Stock. Zootech. International. pp. 22-25.

Pour-Reza, J. and Edriss, M.A. (1997). Effects of dietary sorghum of different tannin concentration and tallow supplementation on the performance of broiler chicks. British Poult. Sci. 38: 512.

Steel, R.G.D. and Torrie, J.H. (1980). Principles and Procedures of Statistics: A Biometrical Approach. $2^{\text {nd }}$ ed. McGraw Hill Books Co. Inc. New York. pp. 63.

Travis, D.K., Tuinstra, M.R. and Hancock, J.D. (2006). Variation in nutritional value of sorghum hybrids with constrasting seed weight characteristics and comparisons with maize in broiler chicks. Crop Sci. 46:695-699

Ugherughe, P.O. and Ekedolum, P.A. (1986). Pasture and Rangland potentials. Annals of Borno. 3: 179-192. 